\title{
Changes in expression of antimicrobial peptides and Fc receptors in the small intestines of neonatal calves during the passive immunity period
}

\author{
H. L. Zhu, ${ }^{1} \odot$ X. W. Zhao, ${ }^{1} \odot$ X. Z. Wang, ${ }^{2}$ Y. X. Qi, ${ }^{1}$ D. W. Huang, ${ }^{1}$ G. L. Cheng, ${ }^{1}$ H. L. Zhao, ${ }^{1}$ and Y. X. Yang ${ }^{1 *} \odot$ \\ ${ }^{1}$ Anhui Province Key Laboratory of Livestock and Poultry Product Safety Engineering, Institute of Animal Science and Veterinary Medicine, \\ Anhui Academy of Agricultural Sciences, Hefei 230031, China \\ ${ }^{2}$ Qinghai Provincial Center for Disease Control and Prevention, Xining 810010, China
}

\begin{abstract}
The contribution of colostrum to passive immunity transfer and intestinal protection is well known; however, the effects of colostrum intake on the expression of antimicrobial peptides (AP) and Fc receptors in the intestine of neonatal calves are unclear. Our aim was to investigate changes in the expression of $\mathrm{AP}$ and $\mathrm{Fc}$ receptor in the small intestine of calves in the first 36 $\mathrm{h}$ postpartum. Twenty-four Holstein bull calves were used in this study, of which 18 calves were administered $3.2 \mathrm{~L}$ of pooled colostrum for each calf per meal via an esophageal tube. Calves were slaughtered at $8 \mathrm{~h} \mathrm{(1}$ meal at 1-2 h), $24 \mathrm{~h}(2$ meals at $1-2 \mathrm{~h}$ and $10-12 \mathrm{~h})$, and $36 \mathrm{~h}$ (3 meals at $1-2 \mathrm{~h}, 10-12 \mathrm{~h}$, and $22-24 \mathrm{~h})$ postpartum. The remaining 6 calves without any milk administration were slaughtered at $2 \mathrm{~h}$ postpartum. Samples of blood and jejunum digesta were collected to determine immunoglobulin concentration using ELISA. Samples of the duodenum, jejunum, and ileum tissues after slaughter were collected to determine AP and Fc receptor expression using quantitative real-time PCR. In calves administered colostrum, IgG concentration in jejunum digesta rapidly decreased in an age-dependent manner (33.41, 9.47, and $0.34 \mathrm{mg} / \mathrm{mL}$ at 8,24 , and $36 \mathrm{~h}$, respectively), whereas serum IgG concentration increased significantly, from $0.25 \mu \mathrm{g} / \mathrm{mL}$ at $2 \mathrm{~h}$ to 21.72 $\mathrm{mg} / \mathrm{mL}$ at $24 \mathrm{~h}$. Cathelicidin-4, $\beta$-defensin (DEFB)-7, and enteric $\beta$-defensin expression was upregulated at $8 \mathrm{~h}$ postpartum in the duodenum and jejunum compared with that at $2 \mathrm{~h}$, but progressive recovery was detected from $24 \mathrm{~h}$ onward. Higher expression of cathelicidin-4, regenerating family member $3 \gamma$, lysozyme ( $L Y Z$ ), $L Y Z 1$, and $L Y Z 2$ and lower expression of $D E F B$, $D E F B 1, D E F B 7, D E F B 10$, and enteric $\beta$-defensin were
\end{abstract}

Received December 23, 2019 .

Accepted May 26, 2020.

*Corresponding author: yyongxin@yahoo.com observed in the duodenum and jejunum compared with the ileum. Differences in AP expression between intestinal regions suggested that the innate immune defense mechanism varied significantly among the duodenum, jejunum, and ileum. No difference in the expression of Fc fragment of the IgG receptor was observed either among ages or small intestinal regions. The Fc $\gamma$ receptor $(F c \gamma R) I a$ and $F c \gamma R I I b$ expression was the highest at $8 \mathrm{~h}$ compared with that at 2, 24, and $36 \mathrm{~h}$, and expres-

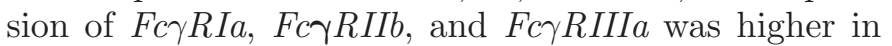
the duodenum and jejunum than in the ileum. These results indicated that $\mathrm{AP}$ and $\mathrm{Fc} \gamma$ receptors might play important roles in intestinal defense during the passive immunity period.

Key words: Fc receptor, antimicrobial peptide, small intestine, neonatal calf

\section{INTRODUCTION}

The rearing of neonatal calves is considered one of the most critical factors in dairy farming, and the immune protective effects of colostrum on calves have been well studied (Weaver et al., 2000; Shivley et al., 2018). Colostrum intake in calves has been reported to have numerous health benefits, including reduced risk of morbidity and mortality, increased growth rate in the preweaning period, and improved first-lactation milk production as cows (Faber et al., 2005; Lago et al., 2018; Lora et al., 2018).

Following birth, the neonatal intestinal immune system must appropriately respond to dietary factors, such as colostrum intake, and microbial colonization to promote intestinal homeostasis. The innate immunity system, as the first line of host defense, can provide rapid and ongoing protection against foreign antigens. Antimicrobial peptides (AP) are important effectors of innate immunity in humans and animals (Salzman et al., 2007; Mukherjee and Hooper, 2015). The $\beta$-defensins $(D E F B)$, cathelicidins $(C A T H L)$, regenerating isletderived protein $3 \gamma(R E G 3 G)$, and lysozymes $(L Y Z)$ are 
the major AP in the mammalian intestine (Mukherjee et al., 2008; Mukherjee and Hooper, 2015). Of these, lysozymes and $R E G 3 G$ are primarily produced by Paneth cells, and cathelicidins and $\beta$-defensins are mainly expressed by intestinal epithelial cells (Santaolalla et al., 2011; Mukherjee and Hooper, 2015). Previous studies have reported that human neonatal intestine has the capacity to produce AP after breastfeeding (Insoft et al., 1996; Kai-Larsen et al., 2007). For example, human cathelicidin $L L-37$ and LYZ have been detected in the feces and meconium of neonates (Kai-Larsen et al., 2007). In calves, a recent study using RNA sequencing demonstrated that several AP, such as DEFB1, $D E F B 4 A$, and $R E G 3 G$, were specifically detected in the jejunum and ileum from 0 to $42 \mathrm{~d}$ postpartum (Liang et al., 2016). These results indicated a need to explore AP expression in the intestine of calves during the passive immunity period.

The transfer of colostrum IgG is implicated in different mechanisms to protect the host against infection, especially in neonates, which present a "naive immune system." The Fc receptors for IgG are classified into 2 distinct functional classes, namely neonatal Fc receptor $(\mathbf{F c R n})$ and $\mathrm{Fc}_{\mathrm{c}} \boldsymbol{\gamma}$ receptor $(\mathbf{F} \mathbf{c} \boldsymbol{\gamma} \mathbf{R})$. The former is expressed on intestinal epithelial cells and is involved in the transfer and recycling of $\mathrm{IgG}$, and the latter is expressed on immune cells (including macrophages, dendritic cells, and lymphocytes) and is responsible for mediating the cellular functions of IgG, including eliminating pathogens, and stimulating the activation and maturation of the immune systems (Bournazos et al., 2015; Castro-Dopico and Clatworthy, 2019). In rodents and humans, IgG transfer across the intestine into blood is mediated by FcRn (Simister and Rees, 1985; Shah et al., 2003), a heterodimer composed of the Fc fragment of IgG receptor $(F c G R T)$ and $\beta-2-$ microglobulin. In ruminants, transfer of colostral IgG across the intestine remains controversial. Several previous studies suggested that intestinal absorption of IgG was dependent on pinocytosis (Weaver et al., 2000; Cervenak and Kacskovics, 2009), whereas other studies indicated that IgG transfer across the intestine was involved in the receptor-mediated pathway (Jochims et al., 1994). Fc $\gamma \mathrm{R}$ is an important regulator in the development of autoimmune and inflammatory bowel diseases in humans (Castro-Dopico and Clatworthy, 2019). Its effect on immune cells is mediated by 2 types of receptors, several activating receptors including Fc $\gamma$ RIa, Fc $\gamma$ RIIa, and Fc $\gamma$ RIIIa, and a single inhibitory receptor, Fc $\gamma$ RIIb. Activating and inhibitory receptors are co-expressed by the majority of immune effector cells, and their relative expression determines the threshold of cell activation. Although these genes have been cloned and characterized in cows (Symons and Clarkson, 1992; Collins et al., 1997), no information is available about $\mathrm{Fc} \gamma \mathrm{R}$ expression in the intestine of calves.

Thus, we hypothesized that colostrum intake would affect the expression of $\mathrm{AP}$ and $\mathrm{Fc}$ receptors in the intestine of calves during the passive immunity period. The objective of this study was to investigate the changes in the expression of AP and Fc receptors along the small intestine (duodenum, jejunum, and ileum), as well as immunoglobulin concentrations of serum and jejunum digesta in calves in the first $36 \mathrm{~h}$ postpartum.

\section{MATERIALS AND METHODS}

\section{Animals, Experimental Design, and Sample Collection}

The animal experiment was conducted at the Chuzhou dairy farm in Anhui province, following protocols approved by the Animal Care Advisory Committee of the Anhui Academy of Agricultural Sciences (no. A11-CS16). Detailed information on the animal experiment design was reported in our previous studies (Qi et al., 2018; Zhao et al., 2018). Briefly, the neonatal Chinese Holstein bull calves were separated from dams immediately after birth. The first 2 milking colostrum samples were taken from healthy, multiparous Holstein dairy cows. Samples of colostrum were pooled in a large tub, aliquoted into plastic bottles, and stored at $-20^{\circ} \mathrm{C}$. Before administering to calves, colostrum was incubated in a water bath at $40^{\circ} \mathrm{C}$; colostrum was provided at $3.2 \mathrm{~L}$ (approximately $8.0 \% \mathrm{BW}$ ) for each calf per meal via an esophageal tube. Twenty-four calves were divided into the 4 age groups as follows: (1) calves without administering any milk were slaughtered at 2 $\mathrm{h}$ postpartum $(2 \mathrm{~h}, \mathrm{n}=6) ;(2)$ calves administered 1 meal of colostrum at 1 to $2 \mathrm{~h}$ and slaughtered at $8 \mathrm{~h}$ postpartum ( $8 \mathrm{~h}, \mathrm{n}=6)$; calves administered 2 meals of colostrum at 1 to $2 \mathrm{~h}$ and 10 to $12 \mathrm{~h}$ and slaughtered at $24 \mathrm{~h}$ postpartum $(24 \mathrm{~h}, \mathrm{n}=6)$; calves administered 3 meals of colostrum at 1 to $2 \mathrm{~h}, 10$ to $12 \mathrm{~h}$, and 22 to $24 \mathrm{~h}$ and slaughtered at $36 \mathrm{~h}$ postpartum $(36 \mathrm{~h}, \mathrm{n}=$ 6). Because colostrum IgG absorption in calves started to decrease from 6 to $12 \mathrm{~h}$, remarkably declined at 12 $\mathrm{h}$, and ceased approximately $24 \mathrm{~h}$ postpartum (Cabral et al., 2012), samples were collected at 2, 8, 24, and 36 $\mathrm{h}$, and used to investigate the changes in the intestinal genes corresponding to colostrum ingestion and absorption in the gut of the neonatal calves.

Blood samples were collected from the jugular vein of each calf without an anticoagulant before the calves were slaughtered. Samples were stored overnight at 
$20^{\circ} \mathrm{C}$ and then centrifuged at $3,000 \times g$ for $15 \mathrm{~min}$ at $4^{\circ} \mathrm{C}$. The supernatant serum was collected and stored at $-20^{\circ} \mathrm{C}$. After the blood samples were collected, calves were immediately slaughtered and the duodenum, jejunum, and ileum segments were separated within $30 \mathrm{~min}$ after opening the abdominal cavity according to previously published methods (Liang et al., 2016; Yang et al., 2019). The samples of the duodenum and jejunum were collected from 4 and $50 \mathrm{~cm}$ distal to the pyloric sphincter, respectively; the samples of the ileum were collected from $10 \mathrm{~cm}$ distal to the ileocecal junction. After collection, all tissue samples were immediately cut and washed with $\mathrm{PBS}\left(\mathrm{pH}=7.0,4^{\circ} \mathrm{C}\right)$ to remove digesta until clean. In addition, approximately $40 \mathrm{~mL}$ of digesta was collected into the tube from the midjejunum segment. Samples of the small intestinal tissue and jejunum digesta were frozen in liquid nitrogen and stored at $-80^{\circ} \mathrm{C}$. Samples from the same 5 calves of each group were used for subsequent analysis.

\section{Immunoglobulin Analysis}

Before immunoglobulin analysis, samples of colostrum and jejunum digesta were centrifuged at 4,000 $\times g$ for $30 \mathrm{~min}$ at $4^{\circ} \mathrm{C}$ (Qi et al., 2018), and the supernatant was transferred into $1.5-\mathrm{mL}$ microcentrifuge tubes. Concentrations of $\operatorname{IgG}, \operatorname{IgA}$, and $\operatorname{IgM}$ in the supernatant of colostrum and jejunum digesta and the serum were measured using bovine ELISA quantitation kits (Bethyl Laboratories, Montgomery, TX). All assays were performed in duplicate according to the manufacturer's instructions. Serum samples from $2 \mathrm{~h}$ calves were not diluted, whereas serum and jejunum digesta samples from calves fed colostrum were diluted to $1: 1,000$ or $1: 1,000,000$ for immunoglobulin analysis. The interplate coefficients of variation for IgG, IgA, and IgM were $5.6 \%, 7.5 \%$, and $6.4 \%$, respectively. The apparent efficiency of absorption (AEA) for IgG was calculated using the following formula (Quigley et al., 1998):

$$
\begin{aligned}
& \mathrm{AEA}= \\
& \frac{\text { serum } \operatorname{IgG}(\mathrm{g} / \mathrm{L}) \times \mathrm{BW}(\mathrm{kg}) \times 0.089(\mathrm{~L} / \mathrm{kg})}{\operatorname{IgG} \text { intake }(\mathrm{g})} \times 100 \%
\end{aligned}
$$

\section{Total RNA Isolation, Reverse Transcription, and Quantitative Real-Time PCR}

Total RNA was isolated from approximately $50 \mathrm{mg}$ of tissue sample using the UNIQ-10 column TRIzol total RNA isolation kit (Sangon Biotech, Shanghai, China) according to the manufacturer's instructions. Isolated
RNA was quantified using a NanoDrop 2000 spectrophotometer (Thermo Fisher Scientific, Wilmington, $\mathrm{DE})$. The RNA integrity was verified by $1.2 \%$ agarose gel and by determining the RNA integrity number value using an Agilent 2100 Bioanalyzer (Agilent Technologies, Santa Clara, CA). The average RNA integrity number values ranged from 7.1 to 9.3. Total RNA (300 ng) was reverse transcribed to cDNA using an EasyScript one-step gDNA removal and cDNA synthesis SuperMix kit (TransGen Biotech, Beijing, China) in a $20-\mu \mathrm{L}$ reaction mixture following the manufacturer's instructions. Reactions were performed under the following conditions: $23^{\circ} \mathrm{C}$ for $10 \mathrm{~min}, 42^{\circ} \mathrm{C}$ for $60 \mathrm{~min}$, and $85^{\circ} \mathrm{C}$ for $2 \mathrm{~min}$. The cDNA was then diluted $1: 5$ in nuclease-free water and stored at $-20^{\circ} \mathrm{C}$ for quantitative real-time (qRT)-PCR analysis. Primers for qRT-PCR (Supplemental Table S1, https://doi.org/10.3168/jds .2019-18113) were designed using Oligo 6.0 software (Molecular Biology Insights Inc., Colorado Springs, $\mathrm{CO})$ and validated for amplification efficiency before use (93-108\%). A LightCycler 480 system (Roche Diagnostics, Mannheim, Germany) was used to perform 20$\mu \mathrm{L}$ qRT-PCR, which contained $10 \mu \mathrm{L} 2 \times$ SYBR premix EX-Taq mix (TransGen Biotech, Beijing, China), $0.5 \mu \mathrm{L}$ each of $10 \mu M$ forward and reverse primers, and $2 \mu \mathrm{L}$ of 1:5-diluted cDNA. Reactions were incubated at $94^{\circ} \mathrm{C}$ for $30 \mathrm{~s}$, followed by 40 cycles at $94^{\circ} \mathrm{C}$ for $5 \mathrm{~s}$ and $60^{\circ} \mathrm{C}$ for 35 s. Finally, a melting curve was generated to evaluate primer specificity for each reaction $\left(95^{\circ} \mathrm{C}\right.$ for $10 \mathrm{~s}$ and $60^{\circ} \mathrm{C}$ for $\left.30 \mathrm{~s}\right)$. Reactions with quantitation cycle $(\mathbf{C q})$ values $<35$ were considered valid and analyzed further, whereas reactions with $\mathrm{Cq}$ values $>35$ were considered undetectable. Gene expression $(\Delta \mathrm{Cq})$ was calculated based on the $\mathrm{Cq}$ values of housekeeping genes (average value of $\beta$-actin and GAPDH) and target genes $\left(\Delta \mathrm{Cq}=\mathrm{Cq}_{\text {target gene }}-\mathrm{Cq}_{\text {housekeeping gene }}\right)$. Higher $\Delta \mathrm{Cq}$ values indicate lower gene expression.

\section{Statistical Analysis}

Individual calves were considered experimental units. Statistical analysis was performed using Statistical Package of Social Science software (version 19.0, IBM, Chicago, IL). Immunoglobulin data were analyzed by one-way ANOVA according to the following model: $\mathrm{Y}$ $=\mu+\mathrm{A}_{\mathrm{i}}+\mathrm{e}_{\mathrm{i}}$, where $\mu=$ the mean, $\mathrm{A}=$ the age effect $(2,8,24$, and $36 \mathrm{~h})$, and $\mathrm{e}=$ the residual error. Gene expression data were analyzed by 2-way ANOVA according to the following model: $Y=\mu+A_{i}+R_{j}+$ $A_{i} R_{j}+e_{i j}$, where $\mu=$ the mean, $A=$ the age effect $(2$, 8,24 , and $36 \mathrm{~h}$ ), $\mathrm{R}=$ the small intestinal region effect (duodenum, jejunum, and ileum), $\mathrm{AR}=$ the age by small intestinal region effect, and $\mathrm{e}=$ the residual er- 
Table 1. Immunoglobulin G, IgA, and IgM concentrations in serum and jejunum digesta of neonatal calves during the passive immunity period $(n=5)$

\begin{tabular}{|c|c|c|c|c|c|c|}
\hline \multirow[b]{2}{*}{ Item } & \multicolumn{4}{|c|}{$\mathrm{Age}^{1}$} & \multirow[b]{2}{*}{ SEM } & \multirow[b]{2}{*}{$P$-value } \\
\hline & $2 \mathrm{~h}$ & $8 \mathrm{~h}$ & $24 \mathrm{~h}$ & $36 \mathrm{~h}$ & & \\
\hline \multicolumn{7}{|c|}{ Serum, mg/mL } \\
\hline $\operatorname{IgG}$ & $0.00025^{\mathrm{d}}$ & $10.96^{\mathrm{c}}$ & $21.72^{\mathrm{a}}$ & $16.49^{\mathrm{b}}$ & 1.88 & $<0.001$ \\
\hline IgA & $0.0003^{\mathrm{c}}$ & $0.27^{\mathrm{b}}$ & $1.53^{\mathrm{a}}$ & $0.75^{\mathrm{ab}}$ & 0.06 & $<0.001$ \\
\hline IgM & $0.0003^{\mathrm{d}}$ & $0.32^{\mathrm{c}}$ & $0.73^{\mathrm{a}}$ & $0.45^{\mathrm{b}}$ & 0.17 & $<0.001$ \\
\hline \multicolumn{7}{|c|}{ Jejunum digesta, $\mathrm{mg} / \mathrm{mL}$} \\
\hline IgG & $59.8^{2}$ & $33.41^{\mathrm{a}}$ & $9.47^{\mathrm{b}}$ & $0.34^{\mathrm{c}}$ & 3.85 & $<0.001$ \\
\hline $\operatorname{IgA}$ & $3.28^{2}$ & $2.57^{\mathrm{a}}$ & $0.23^{\mathrm{b}}$ & $0.07^{\mathrm{b}}$ & 0.26 & $<0.001$ \\
\hline IgM & $2.61^{2}$ & $2.21^{\mathrm{a}}$ & $0.37^{\mathrm{b}}$ & $0.13^{\mathrm{b}}$ & 1.49 & $<0.001$ \\
\hline $\mathrm{AEA},{ }^{3} \%$ & - & $19.47^{\mathrm{a}}$ & $19.30^{\mathrm{a}}$ & $9.76^{\mathrm{b}}$ & 1.33 & $<0.001$ \\
\hline
\end{tabular}

${ }^{\mathrm{a}-\mathrm{d}}$ Means within a row with different superscripts were different among ages $(P<0.05)$.

${ }^{1}$ Age: $2 \mathrm{~h}=$ calves were not administered colostrum and slaughtered $2 \mathrm{~h}$ postpartum; $8 \mathrm{~h}=$ calves were administered 1 meal of colostrum at 1 to $2 \mathrm{~h}$ postpartum and slaughtered $8 \mathrm{~h}$ postpartum; $24 \mathrm{~h}=$ calves were administered 2 meals of colostrum at 1 to $2 \mathrm{~h}$ and 10 to $12 \mathrm{~h}$ postpartum and slaughtered $24 \mathrm{~h}$ postpartum; $36 \mathrm{~h}=$ calves were administered 3 meals of colostrum at 1 to $2 \mathrm{~h}, 10$ to $12 \mathrm{~h}$, and 22 to $24 \mathrm{~h}$ postpartum and slaughtered $36 \mathrm{~h}$ postpartum.

${ }^{2}$ The measurement of $\operatorname{IgG}$, IgA, and IgM in colostrum.

${ }^{3} \mathrm{AEA}=$ apparent efficiency of absorption for IgG.

ror. Finally, differences among $F c \gamma R I a, F c \gamma R I I I a$, and $F c \gamma R I I b$ at a given region (duodenum, jejunum, and ileum) from 2 to $36 \mathrm{~h}$ postpartum were tested using one-way ANOVA. Means were compared using Tukey's test. Differences were considered statistically significant when $P<0.05$, and trends were reported when $0.05<$ $P<0.10$.

\section{RESULTS}

\section{Immunoglobulin Concentrations in the Colostrum, Serum, and Jejunum Digesta}

Concentrations of Ig in the colostrum, jejunum digesta, and serum are shown in Table 1. In the jejunum digesta, concentrations of $\operatorname{IgG}$, IgA, and IgM decreased significantly in a time-dependent manner as colostrum was digested in the gut, from 33.41, 2.57, and $2.21 \mathrm{mg} /$ $\mathrm{mL}$, respectively, at $8 \mathrm{~h}$ to $0.34,0.07$, and $0.13 \mathrm{mg} /$ $\mathrm{mL}$, respectively, at $36 \mathrm{~h}$. Serum concentrations of IgG, $\operatorname{IgA}$, and $\operatorname{IgM}$ were very low at $2 \mathrm{~h}(0.25,0.35$, and 0.31 $\mu \mathrm{g} / \mathrm{mL}$, respectively). After calves received colostrum, serum concentrations of $\operatorname{IgG}, \operatorname{IgA}$, and $\operatorname{IgM}$ were the highest at $24 \mathrm{~h}(21.72,1.53$, and $0.73 \mathrm{mg} / \mathrm{mL}$, respectively).

\section{AP Expression}

Expression of AP in the small intestine of neonatal calves during the first $36 \mathrm{~h}$ of life is shown in Table 2 . Age- and gut region-dependent expression of AP genes was observed along the small intestine of calves during the first $36 \mathrm{~h}$ of life. Expression of REG3G, $L Y Z, L Y Z 1$, $L Y Z 2, D E F B, D E F B 1$, and $D E F B 10$ was gut region dependent $(P<0.001)$. The REG3G, LYZ, LYZ1, and $L Y Z 2$ showed higher expression in the duodenum and jejunum than in the ileum of calves, whereas $D E F B$, $D E F B 1$, and DEFB10 expression was higher in the ileum than in the duodenum and jejunum. Expression of $D E F B 4$ was not different either among ages or among the 3 small intestinal regions; however, its expression tended to be higher in the ileum than in the duodenum $(P=0.09)$. As shown in Figure 1 , the age by small intestinal region interaction was observed for $C A T H L 4, D E F B 7$, and enteric $\beta$-defensin $(E B D ; P$ $<0.05)$. Significant upregulation in $C A T H L 4, D E F B$, and $E B D$ expression in the duodenum and jejunum of calves was observed at $8 \mathrm{~h}(P<0.05)$, but progressive recovery was detected from $24 \mathrm{~h}$ onward. Expression of $C A T H L 4, D E F B$ \%, and $E B D$ in the ileum was not different among ages. At $8 \mathrm{~h}, C A T H L 4$ had higher expression in the duodenum and jejunum than in the ileum, whereas $D E F B$ r 7 and $E B D$ expression at all ages was higher in the ileum than in the duodenum and jejunum.

\section{Fc Receptor Expression}

Expression of Fc receptors in the small intestine of neonatal calves during the passive immunity period is shown in Table 3. Age- and gut region-dependent expression of Fc receptors was observed along the small intestine of neonatal calves. No significant differences were observed in FcGRT expression either among ages or the 3 small intestinal regions. However, Fc $\gamma R I a$ and 
$F c \gamma R I I b$ expression was age and gut region dependent along the small intestine of calves within the first 36 $\mathrm{h}$ of life. Expression of $F_{c} \gamma R I a$ and $F_{c} \gamma R I I b$ was the highest at $8 \mathrm{~h}$ compared with that at 2,24 , and $36 \mathrm{~h}$, and was higher in the duodenum than in the jejunum and ileum $(P<0.01)$. The $F c \gamma R I I I a$ expression was gut region dependent, with a higher level in the duodenum and jejunum than in the ileum $(P<0.01)$. Expression of the activating receptors $F c \gamma R I a$ and Fc $\gamma$ RIIIa was higher than that of the inhibitory receptor $F_{c} \gamma R I I b$ in the 3 small intestinal regions in the first $36 \mathrm{~h}$, with the exception of $F c \gamma R I a$ in the ileum at $24 \mathrm{~h}(P<0.05$, Supplemental Figure S1, https://doi.org/10.3168/jds .2019-18113).

\section{DISCUSSION}

In this study, our results showed that in calves fed colostrum, IgG, IgA, and IgM concentrations in the jejunum digesta rapidly decreased as colostrum passed through the gastrointestinal tract, whereas serum concentrations of $\operatorname{Ig} \mathrm{G}$, IgA, and IgM were significantly increased in a time-dependent manner during the first $24 \mathrm{~h}$ postpartum. Of these, changes in serum IgG concentration are consistent with previous reports (Osaka et al., 2014; Lago et al., 2018). Additionally, the lower serum IgG concentration at $36 \mathrm{~h}$ than at $24 \mathrm{~h}$ was similar to the results reported by Conneely et al. (2014), in which serum IgG concentration was gradually decreased from 24 to $48 \mathrm{~h}$ postpartum when calves further received either 2 or 4 meals of $2 \mathrm{~L}$ of transition milk
(63.3 $\mathrm{g}$ of $\operatorname{IgG} / \mathrm{L})$ following the initial feeding of colostrum $(111.5 \mathrm{~g}$ of $\operatorname{IgG} / \mathrm{L})$ at $8.5 \%$ of BW within $2 \mathrm{~h}$ after birth. These results may likely reflect the catabolism of IgG in serum, transfer to other metabolic pools, or both (Talukder et al., 2002; Cervenak and Kacskovics, 2009). Interestingly, a previous study wherein calves were intravenously injected with ${ }^{125}$ I-labeled $\operatorname{IgG}$ at 48 $\mathrm{h}$ postpartum reported that $68 \%$ of the IgG from blood to the gastrointestinal tract lumen was degraded (Besser et al., 1988). Furthermore, several previous studies reported that the activities of digestive enzymes such as aminopeptidase $\mathrm{A} / \mathrm{N}$ and dipeptidyl peptidase were significantly increased in the small intestinal mucosa of neonatal calves, goats, and pigs that received colostrum (Blättler et al., 2001; Moretti et al., 2012; Rasmussen et al., 2016). Moretti et al. (2012) found that the activities of aminopeptidase N/A and dipeptidyl peptidase were the highest at $36 \mathrm{~h}$ in the small intestinal mucosa of kid goats during the first $96 \mathrm{~h}$ postpartum. This was supported by proteomics analysis demonstrating the digestion of colostrum proteins as colostrum passed through the gastrointestinal tract of piglets (Danielsen et al., 2011). Additionally, in neonatal calves, the gold-labeled IgG was detected in transporting vesicles of enterocytes using immunoelectron-microscopy, and $\mathrm{IgG}$ internalization in the small intestine was identified by 2-dimensional gel electrophoresis-based proteomics approaches (Jochims et al., 1994; Yang et al., 2019). Considering the results of the previous studies and our results of apparent efficiency of absorption together, decreased colostral immunoglobulins in the jejunum di-

Table 2. Relative gene expression ${ }^{1}$ of antimicrobial peptides in the small intestine of neonatal calves during the passive immunity period $(\mathrm{n}=5)$

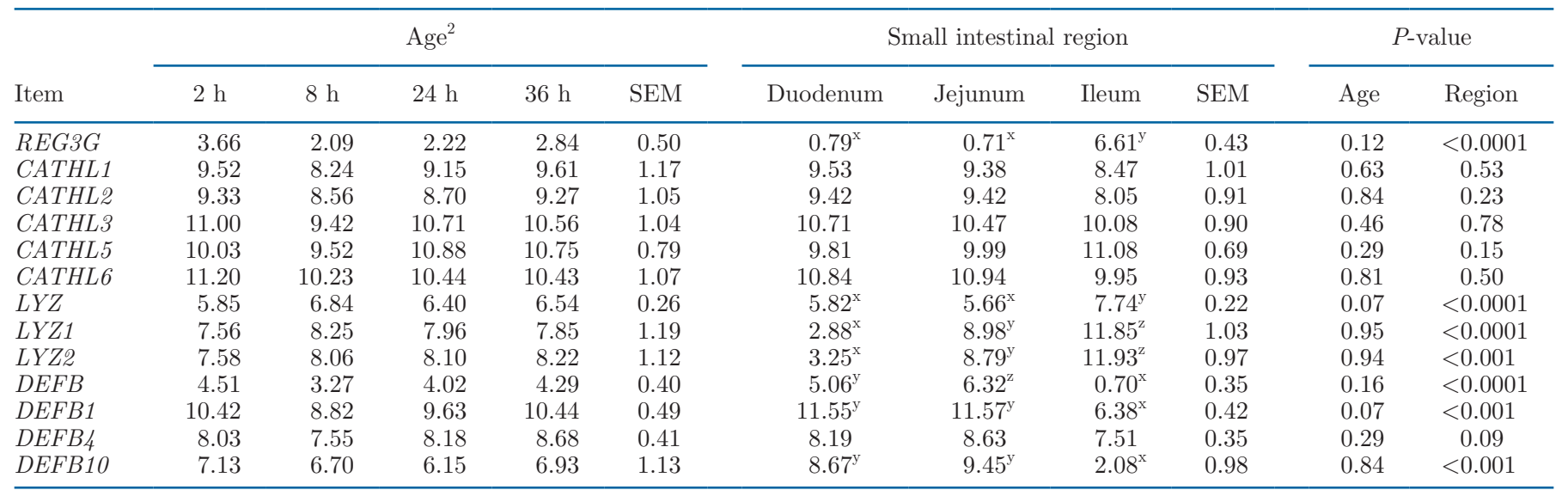

\footnotetext{
${ }^{\mathrm{x}, \mathrm{y}}$ Means within a row with different superscripts were different $(P<0.05)$ among small intestinal regions.

${ }^{1}$ Relative gene expression $(\Delta \mathrm{Cq})=$ quantification cycle $\left(\mathrm{Cq}_{\text {target gene }}\right)-\mathrm{Cq}$ housekeeping gene (average value of $\beta$-actin and GAPDH); higher $\triangle \mathrm{Cq}$ values indicate lower gene expression.

${ }^{2}$ Age: $2 \mathrm{~h}=$ calves were not administered colostrum and slaughtered $2 \mathrm{~h}$ postpartum; $8 \mathrm{~h}=$ calves were administered 1 meal of colostrum at 1 to $2 \mathrm{~h}$ postpartum and slaughtered $8 \mathrm{~h}$ postpartum; $24 \mathrm{~h}=$ calves were administered 2 meals of colostrum at 1 to $2 \mathrm{~h}$ and 10 to $12 \mathrm{~h}$ postpartum and slaughtered $24 \mathrm{~h}$ postpartum; $36 \mathrm{~h}=$ calves were administered 3 meals of colostrum at 1 to $2 \mathrm{~h}, 10$ to $12 \mathrm{~h}$, and 22 to $24 \mathrm{~h}$ postpartum and slaughtered $36 \mathrm{~h}$ postpartum.
} 


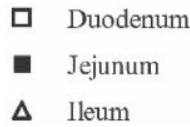

$\Delta \quad$ Ileum

CATHL4

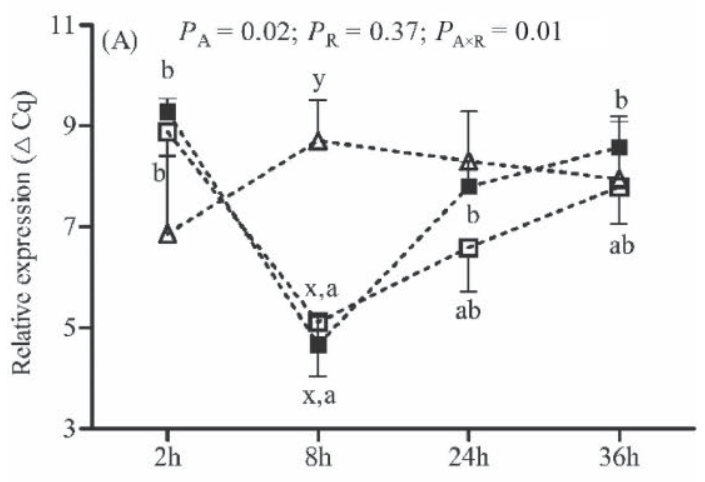

DEFB7

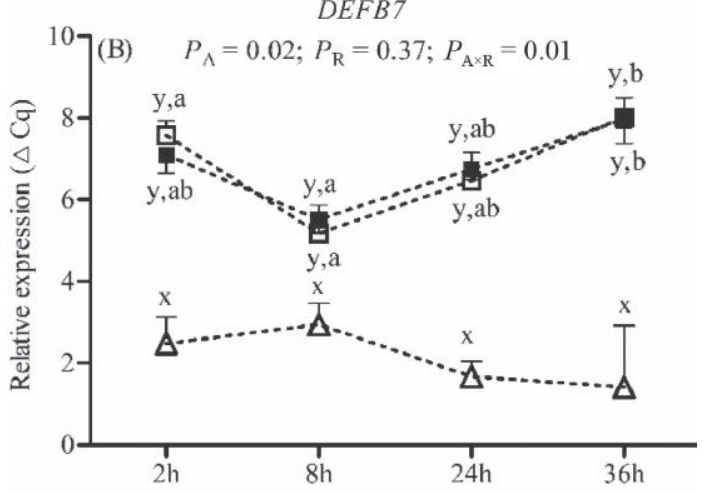

$E B D$

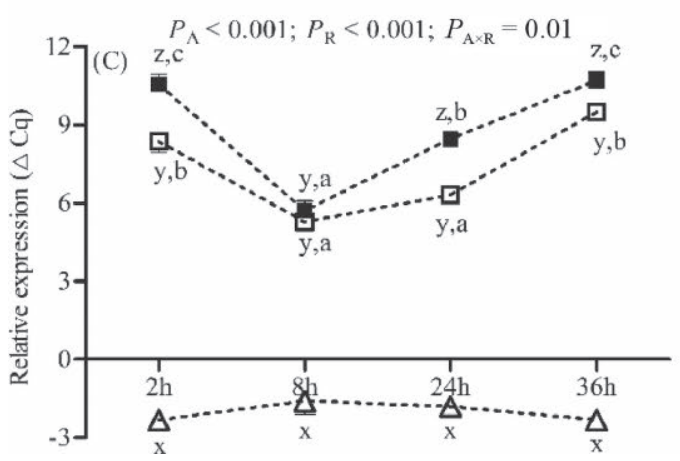

Figure 1. Relative gene expression of cathelicidin-4 (CATHL4), $\beta$-defensin-7 $(D E F B 7)$, and enteric $\beta$-defensin $(E B D)$ in the small intestine of neonatal calves during the passive immunity period. Relative gene expression $(\triangle \mathrm{Cq})=\mathrm{Cq}_{\text {target gene }}(C A T H L 4, D E F B$ 7, or $E B D)-$ Cqhousekeeping gene (average value of $\beta$-actin and $G A P D H$ ); higher $\triangle \mathrm{Cq}$ values indicated lower gene expression. $\mathrm{A}=$ the age effect $(2,8,24$, and $36 \mathrm{~h}$ ), $\mathrm{R}=$ the small intestinal region effect (duodenum, jejunum, and ileum). Different letters a-c indicate expression differences $(P<$ 0.05 ) among $2,8,24$, and $36 \mathrm{~h}$ postpartum at a given small intestinal region. Different letters $\mathrm{x}$ and $\mathrm{y}$ indicate expression differences $(P<$ 0.05 ) among the duodenal, jejunal, and ileal regions at a given age. gesta was likely related to the digestion in the intestinal lumen and retention, intact transfer across the intestine into the blood, or both (Yvon et al., 1993; Quigley et al., 2005; Yang et al., 2019). This observation may be accompanied with intestinal maturation, including cell turnover from fetal-type enterocytes to mature enterocytes and development of digestive secretions (Quigley et al., 2005).

To our knowledge, this is the first study to examine the expression of $\mathrm{AP}$ and $\mathrm{Fc} \gamma \mathrm{R}$ in the small intestine of neonatal calves during the passive immunity period. We observed temporal changes in the expression of several AP in the small intestines of neonatal calves during the passive immunity period. Among them, CATHL4, $D E F B \%$, and $E B D$ were upregulated in the duodenum and jejunum at $8 \mathrm{~h}$ postpartum, and then decreased from 24 to $36 \mathrm{~h}$ postpartum. A previous study reported that, in newborn infants, the antimicrobial activity of the human cathelicidin $L L-37$ was higher in feces (3-8 d after delivery) than in meconium (Kai-Larsen et al., 2007), suggesting that it acts in gut defense during the first several days of life. Induced expression of cathelicidins and $\beta$-defensins in the small intestine of human and rodents has been associated with the presence of microbes (Kai-Larsen et al., 2014; Mukherjee and Hooper, 2015). Furthermore, it was reported that the gut immune system of newborn mice was more susceptible to foreign antigens, including bacterial DNA motifs and vaccines, than that of adult mice (LacroixLamandé et al., 2009). Interestingly, a previous study found that the prevalence of Escherichia coli in the small intestine was significantly decreased within the first $12 \mathrm{~h}$ postpartum as calves were fed colostrum, whereas the density of total bacteria was significantly increased in the small intestine of calves fed colostrum compared with that in calves without colostrum using quantitative real-time PCR (Malmuthuge et al., 2015a). Thus, upregulation of CATHL4, DEFB\%, and $E B D$ in the duodenum and jejunum at $8 \mathrm{~h}$ postpartum observed in our study might be attributed to the rapid response of the naive gut immune system to microbial colonization. The downregulation of CATHL4, DEFB 7, and $E B D$ from 24 to $36 \mathrm{~h}$ postpartum might be the result of coevolution between the colonizing microbes and the neonatal gut innate immune system, as excessive innate immune response to colonizing microbes can cause intestinal inflammation or damage (or both) and has been associated with newborn enteric disease (Buddington and Sangild, 2011; Malmuthuge et al., 2015b). Expression of CATHL4, DEFB 7, and EBD in the ileum did not change within the first $36 \mathrm{~h}$ postpartum, possibly because microbial colonization of the ileum occurs much more rapidly than that of the duodenum and jejunum (Malmuthuge et al., 2015b). Furthermore, we 
Table 3. Relative gene expression ${ }^{1}$ of Fc receptors in the small intestine of neonatal calves during the passive immunity period $(\mathrm{n}=5)$

\begin{tabular}{|c|c|c|c|c|c|c|c|c|c|c|c|}
\hline Item & \multicolumn{5}{|c|}{$\mathrm{Age}^{2}$} & \multicolumn{4}{|c|}{ Small intestinal region } & \multicolumn{2}{|c|}{$P$-value } \\
\hline$\overline{F c G R T}$ & 4.14 & 4.50 & 4.39 & 3.93 & 0.25 & 4.30 & 4.08 & 4.33 & 0.22 & 0.38 & 0.66 \\
\hline$F_{c}$ ?IIb & $10.94^{\mathrm{b}}$ & $9.83^{\mathrm{a}}$ & $10.18^{\mathrm{ab}}$ & $11.03^{\mathrm{b}}$ & 0.27 & $9.94^{\mathrm{x}}$ & $10.35^{\mathrm{xy}}$ & $11.20^{\mathrm{y}}$ & 0.23 & 0.005 & 0.001 \\
\hline Fc?IIIa & 7.52 & 7.07 & 7.50 & 7.81 & 0.24 & $7.17^{\mathrm{x}}$ & $7.15^{\mathrm{x}}$ & $8.11^{\mathrm{y}}$ & 0.21 & 0.21 & 0.003 \\
\hline
\end{tabular}

$\overline{\mathrm{a}, \mathrm{b} ; \mathrm{x}, \mathrm{y}}$ Means within a row with different superscripts were different $(P<0.05)$ among ages or small intestinal regions.

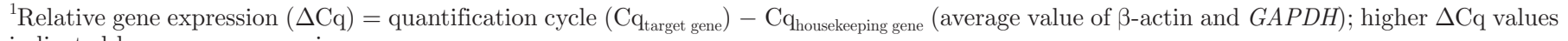
indicated lower gene expression.

${ }^{2}$ Age: $2 \mathrm{~h}=$ calves were not administered colostrum and slaughtered $2 \mathrm{~h}$ postpartum; $8 \mathrm{~h}=$ calves were administered 1 meal of colostrum at 1 to $2 \mathrm{~h}$ postpartum and slaughtered $8 \mathrm{~h}$ postpartum; $24 \mathrm{~h}=$ calves were administered 2 meals of colostrum at 1 to $2 \mathrm{~h}$ and 10 to $12 \mathrm{~h}$ postpartum and slaughtered $24 \mathrm{~h}$ postpartum; $36 \mathrm{~h}=$ calves were administered 3 meals of colostrum at 1 to $2 \mathrm{~h}, 10$ to $12 \mathrm{~h}$, and 22 to $24 \mathrm{~h}$ postpartum and slaughtered $36 \mathrm{~h}$ postpartum.

found that AP expression was region dependent, with higher expression of $R E G 3 G$ and lower expression of $\beta$-defensins (DEFB, DEFB1, DEFB $\%, D E F B 10$, and $E B D)$ in the duodenum and jejunum than in the ileum. Similarly, a recent RNA-Seq study of the small intestine in calves from 0 to $42 \mathrm{~d}$ postpartum reported that $R E G 3 G$ was enriched in the jejunum, whereas $D E F B 405, D E F B 5$, and DEFB7 were enriched in the ileum (Liang et al., 2016). Tarver et al. (1998) observed higher $E B D$ abundance in the distal small intestine than in the proximal and middle small intestine in newborn calves by Northern blot analysis. Additionally, recent studies reported that the prevalence of Bifidobacterium spp. was higher in the proximal jejunum than in the distal jejunum and ileum regardless of colostrum feeding and age, whereas the density of total bacteria (number of copies of $16 \mathrm{~S}$ rRNA genes) was not different between the ileum and jejunum of calves receiving colostrum (Malmuthuge et al., 2015a; Fischer et al., 2018). As discussed previously, the differences in AP expression among the intestinal regions might be related to regionspecific intrinsic expression profiles and be affected by the intestinal microbiome and environment (Blättler et al., 2001; Van den Abbeele et al., 2011). In the small ruminants, however, the mRNA expression of $\beta$-defensin 1 and 2 was higher in the jejunum than in the ileum of the fetuses ( $130 \mathrm{~d}$ gestation and $145 \mathrm{~d}$ term) and neonates (3-5 d postpartum) of sheep (Huttner et al., 1998; Meyerholz et al., 2004). It is likely that AP in the small intestine of neonatal ruminants display speciesspecific patterns during early postnatal development. Collectively, our results indicated that AP might play important roles in the immune response of the neonatal intestine to the composition and location of intestinal microbiota. However, further studies are needed to explore the relationship between AP expression and early microbiota colonization in the neonatal intestine.
In this study, we observed significant upregulation of Fc $\gamma R I a$ and $F c \gamma R I I b$ expression in the duodenum and jejunum during the first $8 \mathrm{~h}$ and a progressive decrease after $24 \mathrm{~h}$. This observation might be related to the fact that the majority of IgG uptake occurs in the small intestine during the first $12 \mathrm{~h}$ postpartum (Cabral et al., 2012; Osaka et al., 2014), which allows internalized IgG to bind to immune cells, such as macrophages, dendritic cells, and B lymphocytes located in the lamina propria of the small intestine, and activate $F_{c} \gamma R$ expression (Kacskovics, 2004; Castro-Dopico and Clatworthy, 2019). Moreover, the higher expression of $F c \gamma R I a, F c \gamma R I I b$, and Fc $\gamma R I I I a$ in the duodenum and jejunum than in the ileum implies that the duodenum and jejunum are better protected against pathogen invasion via the $\operatorname{IgG}-\mathrm{Fc} \gamma \mathrm{R}$ signaling pathway. These significant differences in expression might be associated with differences in the duration of $F c \gamma R$ exposure to internalized IgG in these regions. Supporting this idea, our recent study (Yang et al., 2019) demonstrated that IgG internalization is delayed in the ileum compared with that in the duodenum and jejunum, with internalized IgG observed from 8 to $24 \mathrm{~h}$ postpartum in the duodenum and jejunum, but detected only at 24 to 36 $\mathrm{h}$ postpartum in the ileum. Crosslinking of the activating receptor $\mathrm{Fc} \gamma \mathrm{R}$ by $\operatorname{IgG}$ leads to the phosphorylation of immunoreceptor tyrosine-based activating motifs and the initiation of an activating signaling cascade. The inhibitory receptor $\mathrm{Fc} \gamma \mathrm{RIIb}$, via simultaneous crosslinking of the activating receptor $\mathrm{Fc} \gamma \mathrm{R}$, leads to phosphorylation of immunoreceptor tyrosine-based inhibitory motif, initiating the recruitment of inositol phosphatases to dampen IgG-mediated activating responses (Castro-Dopico and Clatworthy, 2019). A recent study in neonatal mice found that maternal IgG and IgA dampened $\mathrm{T}$ helper cell response and resulted in tolerance of the adaptive immune response (Koch et 
al., 2016). These results indicated that the crosslinking of $\mathrm{Fc} \gamma \mathrm{R}$ on mucosal dendritic cells by IgG might be associated with the modulation of commensal microbes or microbial components. In this study, we observed higher expression of the activating receptors $F_{c} \gamma R I a$ and $F_{c} \gamma R I I I a$ than the inhibitory receptor $F_{c} \gamma R I I b$ in almost all small intestinal regions from $2 \mathrm{~h}$ to $36 \mathrm{~h}$ postpartum, suggesting that activating the IgG-Fc $\gamma \mathrm{R}$ signaling pathway might play important roles in presenting antigens to the innate immune cells for a rapid, noninflammatory clearance during the passive immunity period (Koch et al., 2016). In addition, several cytokines such as tumor necrosis factor- $\alpha$ and interferon- $\gamma$, involved in stimulating $\mathrm{Fc} \gamma \mathrm{R}$ expression in monocytes, neutrophils, and endotheliocytes, have higher concentrations in the colostrum than in mature milk (Pan et al., 1998; Hagiwara et al., 2000). Thus, we speculated that the expression of $\mathrm{Fc} \gamma \mathrm{R}$ in the intestinal epithelial cells might related to the colostrum components and intestinal microbiome and contribute to immunological protection against infection. However, further studies are needed to verify whether the expression of these $\mathrm{Fc} \gamma \mathrm{R}$ is related to colostral IgG, cytokines, and bacteria in the small intestine at the protein level using in vitro and in vivo models, which will provide a better understanding of the immunoregulatory roles of $\mathrm{Fc} \gamma \mathrm{R}$.

\section{CONCLUSIONS}

This study is the first to report the expression of $\mathrm{AP}$ and $\mathrm{Fc}$ receptors in the duodenal, jejunal, and ileal regions of the small intestine of neonatal calves during passive immunity transfer. We found that the IgG concentration in the jejunum digesta significantly decreased in a time-dependent manner. Expression of CATHL4, DEFB 7, and EBD was temporally upregulated in the duodenum and jejunum at $8 \mathrm{~h}$ postpartum. Higher expression of REG3G,LYZ, and CATHL4 and lower $D E F B$ expression were observed in the duodenum and jejunum than in the ileum, indicating that these AP differentially contribute to the defense of different small intestinal regions. Furthermore, this study revealed temporal and regional differences in the expression of $F c \gamma R I a$ and $F c \gamma R I I b$ in the small intestine as colostrum passed through the gastrointestinal tract. Collectively, these data indicate that AP and Fc $\gamma$ receptors could contribute to the intestinal defense of neonatal calves during the passive immunity period. These findings provide novel information to explore the intestine-colostrum interactions toward a system-level understanding of the intestinal function of neonatal calves.

\section{ACKNOWLEDGMENTS}

This work was supported by the National Natural Science Foundation of China (no. 31572434) and the Science and Technology Program of Anhui Province (no. 201903a06020013 and 1704A07020066; China). The authors have not stated any conflicts of interest.

\section{REFERENCES}

Besser, T. E., T. C. McGuire, C. C. Gay, and L. C. Pritchett. 1988 Transfer of functional immunoglobulin $\mathrm{G}$ ( $\mathrm{IgG}$ ) antibody into the gastrointestinal tract accounts for IgG clearance in calves. J. Virol. 62:2234-2237. https://doi.org/10.1128/JVI.62.7.2234-2237.1988.

Blättler, U., H. M. Hammon, C. Morel, C. Philipona, A. Rauprich, V. Romé, I. Le Huërou-Luron, P. Guilloteau, and J. W. Blum. 2001. Feeding colostrum, its composition and feeding duration variably modify proliferation and morphology of the intestine and digestive enzyme activities of neonatal calves. J. Nutr. 131:1256-1263. https://doi.org/10.1093/jn/131.4.1256.

Bournazos, S., D. J. DiLillo, and J. V. Ravetch. 2015. The role of Fc-Fc $\gamma \mathrm{R}$ interactions in IgG-mediated microbial neutralization. J. Exp. Med. 212:1361-1369. https://doi.org/10.1084/jem.20151267.

Buddington, R. K., and P. T. Sangild. 2011. Companion animals symposium: Development of the mammalian gastrointestinal tract, the resident microbiota, and the role of diet in early life. J. Anim. Sci. 89:1506-1519. https://doi.org/10.2527/jas.2010-3705.

Cabral, R. G., E. J. Kent, D. M. Haines, and P. S. Erickson. 2012. Addition of sodium bicarbonate to either 1 or 2 feedings of colostrum replacer: Effect on uptake and rate of absorption of immunoglobulin G in neonatal calves. J. Dairy Sci. 95:3337-3341. https://doi .org/10.3168/jds.2011-5137.

Castro-Dopico, T., and M. R. Clatworthy. 2019. IgG and Fc $\gamma$ receptors in intestinal immunity and inflammation. Front. Immunol. 10:805. https://doi.org/10.3389/fimmu.2019.00805.

Cervenak, J., and I. Kacskovics. 2009. The neonatal Fc receptor plays a crucial role in the metabolism of IgG in livestock animals. Vet. Immunol. Immunopathol. 128:171-177. https://doi.org/10.1016/j .vetimm.2008.10.300.

Collins, R. A., K. I. Gelder, and C. J. Howard. 1997. Nucleotide sequence of cattle FcGRIII: Its identification in gammadelta T cells. Immunogenetics 45:440-443. https://doi.org/10.1007/ s002510050228.

Conneely, M., D. P. Berry, J. P. Murphy, I. Lorenz, M. L. Doherty, and E. Kennedy. 2014. Effect of feeding colostrum at different volumes and subsequent number of transition milk feeds on the serum immunoglobulin G concentration and health status of dairy calves. J. Dairy Sci. 97:6991-7000. https://doi.org/10.3168/jds.2013-7494.

Danielsen, M., L. J. Pedersen, and E. Bendixen. 2011. An in vivo characterization of colostrum protein uptake in porcine gut during early lactation. J. Proteomics 74:101-109. https://doi.org/10 .1016/j.jprot.2010.08.011.

Faber, S. N., N. E. Faber, T. C. McCauley, and R. L. Ax. 2005. Case study: Effects of colostrum ingestion on lactational performance. Prof. Anim. Sci. 21:420-425. https://doi.org/10.15232/S1080 $-7446(15) 31240-7$

Fischer, A. J., Y. Song, Z. He, D. M. Haines, L. L. Guan, and M. A. Steele. 2018. Effect of delaying colostrum feeding on passive transfer and intestinal bacterial colonization in neonatal male Holstein calves. J. Dairy Sci. 101:3099-3109. https://doi.org/10.3168/jds .2017-13397.

Hagiwara, K., S. Kataoka, H. Yamanaka, R. Kirisawa, and H. Iwai. 2000. Detection of cytokines in bovine colostrum. Vet. Immunol. Immunopathol. 76:183-190. https://doi.org/10.1016/S0165 -2427(00)00213-0.

Huttner, K. M., D. J. Brezinski-Caliguri, M. M. Mahoney, and G. Diamond. 1998. Antimicrobial peptide expression is developmentally 
regulated in the ovine gastrointestinal tract. J. Nutr. 128:297S299S. https://doi.org/10.1093/jn/128.2.297S.

Insoft, R. M., I. R. Sanderson, and W. A. Walker. 1996. Development of immune function in the intestine and its role in neonatal diseases. Pediatr. Clin. North Am. 43:551-571. https://doi.org/10 .1016/S0031-3955(05)70420-X.

Jochims, K., F. J. Kaup, W. Drommer, and M. Pickel. 1994. An immunoelectron microscopic investigation of colostral IgG absorption across the intestine of newborn calves. Res. Vet. Sci. 57:75-80. https://doi.org/10.1016/0034-5288(94)90085-X.

Kacskovics, I. 2004. Fc receptors in livestock species. Vet. Immunol. Immunopathol. 102:351-362. https://doi.org/10.1016/j.vetimm 2004.06.008.

Kai-Larsen, Y., G. Bergsson, G. H. Gudmundsson, G. Printz, H. Jörnvall, G. Marchini, and B. Agerberth. 2007. Antimicrobial components of the neonatal gut affected upon colonization. Pediatr. Res. 61:530-536. https://doi.org/10.1203/pdr.0b013e318045be83.

Kai-Larsen, Y., G. H. Gudmundsson, and B. Agerberth. 2014. A review of the innate immune defence of the human foetus and newborn, with the emphasis on antimicrobial peptides. Acta Paediatr. 103:1000-1008. https://doi.org/10.1111/apa.12700.

Koch, M. A., G. L. Reiner, K. A. Lugo, L. S. M. Kreuk, A. G. Stanbery, E. Ansaldo, T. D. Seher, W. B. Ludington, and G. M. Barton. 2016. Maternal IgG and IgA antibodies dampen mucosal T helper cell responses in early life. Cell 165:827-841. https://doi .org/10.1016/j.cell.2016.04.055.

Lacroix-Lamandé, S., N. Rochereau, R. Mancassola, M. Barrier, A. Clauzon, and F. Laurent. 2009. Neonate intestinal immune response to $\mathrm{CpG}$ oligodeoxynucleotide stimulation. PLoS One 4:e8291. https://doi.org/10.1371/journal.pone.0008291.

Lago, A., M. Socha, A. Geiger, D. Cook, N. Silva-Del-Río, C. Blanc, R. Quesnell, and C. Leonardi. 2018. Efficacy of colostrum replacer versus maternal colostrum on immunological status, health, and growth of preweaned dairy calves. J. Dairy Sci. 101:1344-1354. https://doi.org/10.3168/jds.2017-13032.

Liang, G., N. Malmuthuge, H. Bao, P. Stothard, P. J. Griebel, and L. L. Guan. 2016. Transcriptome analysis reveals regional and temporal differences in mucosal immune system development in the small intestine of neonatal calves. BMC Genomics 17:602. https:/ /doi.org/10.1186/s12864-016-2957-y.

Lora, I., F. Gottardo, B. Contiero, B. Dall Ava, L. Bonfanti, A. Stefani, and A. Barberio. 2018. Association between passive immunity and health status of dairy calves under 30 days of age. Prev. Vet. Med. 152:12-15. https://doi.org/10.1016/j.prevetmed.2018.01.009.

Malmuthuge, N., Y. Chen, G. Liang, L. A. Goonewardene, and L. L. Guan. 2015a. Heat-treated colostrum feeding promotes beneficial bacteria colonization in the small intestine of neonatal calves. J. Dairy Sci. 98:8044-8053. https://doi.org/10.3168/jds.2015-9607.

Malmuthuge, N., P. J. Griebel, and L. L. Guan. 2015b. The gut microbiome and its potential role in the development and function of newborn calf gastrointestinal tract. Front. Vet. Sci. 2:36. https:// doi.org/10.3389/fvets.2015.00036.

Meyerholz, D. K., J. M. Gallup, B. M. Grubor, R. B. Evans, B. F. Tack, P. B. McCray Jr., and M. R. Ackermann. 2004. Developmental expression and distribution of sheep $\beta$-defensin-2. Dev. Comp. Immunol. 28:171-178. https://doi.org/10.1016/S0145 $-305 \mathrm{X}(03) 00105-8$.

Moretti, D. B., W. M. Nordi, A. L. Lima, P. Pauletti, I. Susin, and R. Machado-Neto. 2012. Enzyme activity in the small intestine of goat kids during the period of passive immunity acquisition. Small Rumin. Res. 105:321-328. https://doi.org/10.1016/j.smallrumres .2012.01.014.

Mukherjee, S., and L. V. Hooper. 2015. Antimicrobial defense of the intestine. Immunity 42:28-39. https://doi.org/10.1016/j.immuni .2014.12.028.

Mukherjee, S., S. Vaishnava, and L. V. Hooper. 2008. Multi-layered regulation of intestinal antimicrobial defense. Cell. Mol. Life Sci. 65:3019-3027. https://doi.org/10.1007/s00018-008-8182-3.

Osaka, I., Y. Matsui, and F. Terada. 2014. Effect of the mass of immunoglobulin $(\mathrm{Ig}) \mathrm{G}$ intake and age at first colostrum feeding on serum IgG concentration in Holstein calves. J. Dairy Sci. 97:66086612. https://doi.org/10.3168/jds.2013-7571.

Pan, L. F., R. A. Kreisle, and Y. D. Shi. 1998. Detection of Fcgamma receptors on human endothelial cells stimulated with cytokines tumour necrosis factor-alpha (TNF-alpha) and interferon-gamma (IFN-gamma). Clin. Exp. Immunol. 112:533-538. https://doi.org/ 10.1046/j.1365-2249.1998.00597.x.

Qi, Y., X. Zhao, D. Huang, X. Pan, Y. Yang, H. Zhao, H. Hu, and G. Cheng. 2018. Exploration of the relationship between intestinal colostrum or milk, and serum metabolites in neonatal calves by metabolomics analysis. J. Agric. Food Chem. 66:7200-7208. https: //doi.org/10.1021/acs.jafc.8b01621.

Quigley, J. D. III, J. J. Drewry, and K. R. Martin. 1998. Estimation of plasma volume in Holstein and Jersey calves. J. Dairy Sci. 81:1308-1312. https://doi.org/10.3168/jds.S0022-0302(98)75693 $-0$.

Quigley, J. D., C. J. Hammer, L. E. Russel, and J. Polo. 2005. Passive immunity in newborn calves. Pages 135-157 in Calf and Heifer Rearing. P. C. Garnsworthy, ed. Nottingham University Press, Nottingham, UK

Rasmussen, S. O., L. Martin, M. V. Østergaard, S. Rudloff, Y. Li, M. Roggenbuck, S. B. Bering, and P. T. Sangild. 2016. Bovine colostrum improves neonatal growth, digestive function, and gut immunity relative to donor human milk and infant formula in preterm pigs. Am. J. Physiol. Gastrointest. Liver Physiol. 311:G480-G491. https://doi.org/10.1152/ajpgi.00139.2016.

Salzman, N. H., M. A. Underwood, and C. L. Bevins. 2007. Paneth cells, defensins, and the commensal microbiota: a hypothesis on intimate interplay at the intestinal mucosa. Semin. Immunol. 19:70-83. https://doi.org/10.1016/j.smim.2007.04.002.

Santaolalla, R., M. Fukata, and M. T. Abreu. 2011. Innate immunity in the small intestine. Curr. Opin. Gastroenterol. 27:125-131. https://doi.org/10.1097/MOG.0b013e3283438dea.

Shah, U., B. L. Dickinson, R. S. Blumberg, N. E. Simister, W. I. Lencer, and W. A. Walker. 2003. Distribution of the IgG Fc receptor, FcRn, in the human fetal intestine. Pediatr. Res. 53:295-301. https://doi.org/10.1203/00006450-200302000-00015.

Shivley, C. B., J. E. Lombard, N. J. Urie, C. A. Kopral, M. Santin, T. J. Earleywine, J. D. Olson, and F. B. Garry. 2018. Preweaned heifer management on US dairy operations: Part VI. Factors associated with average daily gain in preweaned dairy heifer calves. J. Dairy Sci. 101:9245-9258. https://doi.org/10.3168/jds.2017-14022.

Simister, N. E., and A. R. Rees. 1985. Isolation and characterization of an Fc receptor from neonatal rat small intestine. Eur. J. Immunol. 15:733-738. https://doi.org/10.1002/eji.1830150718.

Symons, D. B., and C. A. Clarkson. 1992. Genomic organisation and sequence of the extracellular domain exons of the bovine Fc gamma RI receptor, and evidence for restricted binding of ruminant IgG to U937 cells. Mol. Immunol. 29:1407-1413. https://doi.org/ 10.1016/0161-5890(92)90178-Z.

Talukder, M. J. R., T. Takeuchi, and E. Harada. 2002. Transport of colostral macromolecules into the cerebrospinal fluid via plasma in newborn calves. J. Dairy Sci. 85:514-524. https://doi.org/10.3168/ jds.S0022-0302(02)74103-9.

Tarver, A. P., D. P. Clark, G. Diamond, J. P. Russell, H. ErdjumentBromage, P. Tempst, K. S. Cohen, D. E. Jones, R. W. Sweeney, M. Wines, S. Hwang, and C. L. Bevins. 1998. Enteric beta-defensin: Molecular cloning and characterization of a gene with inducible intestinal epithelial cell expression associated with Cryptosporidium parvum infection. Infect. Immun. 66:1045-1056. https://doi.org/10 .1128/IAI.66.3.1045-1056.1998.

Van den Abbeele, P., T. Van de Wiele, W. Verstraete, and S. Possemiers. 2011. The host selects mucosal and luminal associations of coevolved gut microorganisms: A novel concept. FEMS Microbiol. Rev. 35:681-704. https://doi.org/10.1111/j.1574-6976.2011.00270 .x.

Weaver, D. M., J. W. Tyler, D. C. VanMetre, D. E. Hostetler, and G. M. Barrington. 2000. Passive transfer of colostral immunoglobulins in calves. J. Vet. Intern. Med. 14:569-577. https://doi.org/10 $.1111 /$ j.1939-1676.2000.tb02278.x. 
Yang, Y., X. Zhao, D. Huang, J. Wang, Y. Qi, L. Jiang, H. Zhao, and G. Cheng. 2019. Changes in intestinal proteins induced by colostrum uptake in neonatal calves: Analysis by two-dimensional gel electrophoresis-based proteomics analysis. Anim. Prod. Sci. 59:1483-1490. https://doi.org/10.1071/AN18242.

Yvon, M., D. Levieux, M. C. Valluy, J. P. Pélissier, and P. P. Mirand. 1993. Colostrum protein digestion in newborn lambs. J. Nutr. 123:586-596. https://doi.org/10.1093/jn/123.3.586.

Zhao, X. W., Y. X. Qi, D. W. Huang, X. C. Pan, G. L. Cheng, H. L. Zhao, and Y. X. Yang. 2018. Changes in serum metabolites in response to ingested colostrum and milk in neonatal calves, mea- sured by nuclear magnetic resonance-based metabolomics analysis. J. Dairy Sci. 101:7168-7181. https://doi.org/10.3168/jds.2017 $-14287$.

\section{ORCIDS}

H. L. Zhu ๑ https://orcid.org/0000-0001-5273-5090

X. W. Zhao ๑ https://orcid.org/0000-0003-0952-0785

Y. X. Yang (1) https://orcid.org/0000-0002-9596-9636 